\title{
Adjectives in Kurdish language: Comparison between dialects
}

\author{
Hasan Karacan', Hewa Salam Khalid ${ }^{2}$
}

Received: May 12, 2016 Reviewed: August 16, 2016 Accepted: August 20, 2016

\begin{abstract}
Adjectives in Kurdish language is studied in this article, examples are taken in Northern Kurmanji dialect, while the phonetic of the most adjectives are shown in Central Kurmanji 'Sorani', and Zazaki as well. It is found that there are not major differences between Kurdish dialects in terms of morphology. The taken adjectives mostly are same or have a minor phonetical change. Types of Kurdish adjectives in terms of semantics and structure are noticed. Also, three kinds of comparative degree are analysed. Kurdish adjectives are compared with Persian and English adjectives; as generally observed, Kurdish and Persian languages have a lot in common, and it is clear in our examples. In contrast, Kurdish and English have little in common.
\end{abstract}

Keywords; Kurdish language, lexical categories, adjective, Kurdish dialects, Kurmanji, Sorani, Zazaki

Recommended citation:

Karacan, H. \& Khalid, H. S. (2016). Adjectives in Kurdish language: Comparison between dialects.

International Journal of Kurdish Studies 2 (2), 15 - 23.

\footnotetext{
${ }^{1}$ Corresponding Author: Asst. Prof. Dr. Kurdish Department, Dicle University, Diyarbakir, Turkey. E-mail: hasan.karacan@dicle.edu.tr

${ }^{2}$ Department of Kurdish language, Koya University Kurdistan Region of Iraq, University Park, Danielle

Mitterrand Boulevard, Koysinjaq KOY45. E-mail: hewa.salam@koyauniversity.org
} 


\section{INTRODUCTION}

An adjective is an independent part of speech. Some languages have special forms for adjective while some others have not. Taking English as an example, Baker (2003) thinks that there is nothing special about adjectives. They are already distinguished from verbs by not licensing a specifier, and from nouns by not having a referential index. Ideally, this should be enough to completely characterize their behaviour. Regarding their tasks he stated that the most obvious distinctive characteristic of adjectives is that they modify nouns directly, in the so-called attributive construction. Nouns and verbs cannot do this.

Similar with English, in Kurdish also adjective does not have special form, and one may differentiate it with noun and other parts of speech by its meaning (Marf, 2001). Generally talking about the mode of adjective, there are two categorizations; one of them concentrates on adjective in terms of meaning, and the other one concentrates on the grammatical structure of adjectives.

In terms of meaning, adjective is divided into three main kinds; which are qualitative adjective, quantitative adjective and adjectives for absence. In terms of grammatical structure of adjectives, it is divided into two main parts that are simple and compound adjectives. Regarding its speciality, an adjective has three forms of comparative degree. The first one is regular adjective that is called base or positive degree. The positive degree describes a noun without comparing it to another noun. The second type is comparative degree, which compares two nouns. And the third one is called the superlative degree that highlights a noun among three or more samples (Marf, 2001) (Yildirim, 2012).

It is important to make a comparison among the Kurdish dialects about the adjectives. This would help us to find the changes between the dialects in terms of morphology. As such, the similarities and differences between a specific adjective among Kurdish dialects would be clearer. The questions of this project are that "How an adjective works in Kurdish language" and "How the comparison is made." To answer these questions, multi methods are used, which are; Synchronic method, descriptive method and comparative method.

In this study, all types of adjective are analysed, and they are clarified with Kurdish examples in Kurmanji dialect, also the phonetical changes of adjectives are shown among Kurdish dialects; Northern Kurmanji 'Kurmanji', Central Kurmanji 'Sorani', and Zazaki. Moreover, adjectives in Kurdish are compared with adjectivea in other languages like English and Persian. Eventually, the study sums up the achievements.

\section{What is an adjective?}

Adjective 'hevalnav or ئاولنّاو in Kurdish, can generally be defined as "a word that modifies, or qualifies, a noun or pronoun, in one of three forms of comparative degree: positive (bihêz - strong, ciwan - beautiful), comparative (bihêztir - stronger, ciwantir - more beautiful), or superlative (behêztrîn - strongest, ciwantirîn - most beautiful). It is also described as "a word whose main syntactic role is to modify a noun or pronoun, giving more information about the noun or pronoun's (Amer, 2013, p. 24). 
In addition, there is another view that describes an adjective as a part of speech which describes, identifies, or quantifies a noun or a pronoun. So basically, the main function of an adjective is to modify a noun or a pronoun. As such, instead of just one word, a group of words with a subject and a verb can also function as an adjective. The group of words is called an adjective clause.

These definitions describe adjectives in terms of structure, and its classification in terms of semantics is partially ignored. Additionally, Oxford's Dictionary defines adjective as a word that describes a noun, giving extra information about it. For example: a sweet taste, a red apple, a technical problem, an Italian woman (Oxford's Dictionary, 2016).

As generally known, each language has its own specifications, so Kurdish adjectives would have some differences with adjectives in other languages. So that Kurdish linguistics have described adjective by taking Kurdish examples. The Kurdish linguist Awrehmani Haji Marf defines adjective, and his description is quoted by many other Kurdish linguists. He believes that adjective is a " a type of word. Qualitative, properties and indication is seen within its meaning. This speciality of adjective is clear in both syntax and morphology." (Marf, 2001, p. 58). This definition is more about the meaning of adjective than structure.

Generally, an adjective has some specialities that differentiate it with a noun. It describes a noun, and works as a determinative in syntax. All of the adjectives, within a phrase or a sentence, determinate a noun, and they do not determinate each other; for example

- keçeke ciwan $\hat{u}$ nazdar (a beautiful dainty girl)

- zelamekî lawaz $\hat{u}$ dirêj (a thin tall man)

In both examples above, the adjectives describe the nouns. Both (ciwan, nazdar) determinate the girl, and the same is true for the second example. Furthermore, there are syntactic environments in which only an adjective can appear; first, adjectives can be direct attributive modifiers of nouns, but nouns and verbs cannot be. Secondly, adjectives can be the complements of degree heads like so, as, too, and how in English, but neither nominal nor verbal projections can be. Third, adjectives can be resultative secondary predicates, unlike nouns and verbs (Baker, 2003).

In Kurdish morphology, an adjective does not have any special form, but appears in the same syntactic environments that were mentioned above. So, it helps us to distinguish it from other lexical categories.

There are some examples of Kurdish adjectives presented in Table 1.

\begin{tabular}{|c|c|c|c|}
\hline $\begin{array}{l}\text { Kurdish - Northern } \\
\text { Kurmanji }\end{array}$ & $\begin{array}{l}\text { Kurdish-Central } \\
\text { Kurmanji }\end{array}$ & Kurdish - Zazaki & English \\
\hline$s p \hat{\imath}$ & $s p \hat{\imath}$ & $s p \hat{\imath}$ & white \\
\hline ciwan & ciwan & ciwan & Nice \\
\hline bilind & Bilnd-berz & Bilnd - berz & Tall \\
\hline Lawaz - zeif & Lawaz - zeif & zeif & Thin \\
\hline kurdî & kurdî & Kurdkî & Kurdish \\
\hline rûxweş & ruxoş & riweş & Amiable \\
\hline Belengaz-feqîr & Hejar - feqîr & Feqîr - Belengaz & Poor \\
\hline
\end{tabular}




\begin{tabular}{llll} 
din & dîke & Bin & Other \\
tamxweş & tamxoş & tamweş & Delirious \\
bêxem & bêxem & bêxem & complacent \\
şukrdar & supasguzar & sipasdar & Thankful \\
\hline
\end{tabular}

By looking the mentioned examples in the Table 1, it will be clear that adjectives are very similar among the Kurdish dialects, and there are only minor phonetic changes in some of them. For example the phonetic of ' $x w e$ ' in Northern Kurmanji become ' $x o$ ' in Central Kurmanji, and 'we' in Zazaki. It is also true for other lexical categories as well. Moreover, some adjectives come into Kurdish from another languages and they are used as a Kurdish word, for example; 'zeif, feqîr' are Arabic adjectives but Kurds also use them due to language contact.

Generally, there are two types of categorizing adjective;

1. Qualitative adjective: An adjective used to identify the qualities or features of a person or thing (Marf, 2001). There are some types of this kind of adjective;

- Colours: (Sor - red, reş - black, kesik - green)

- Properties (sor-salty, germ - hot, sivik - light)

- Features; (ruxweş - amiable, îmandar - faithful).

2. Quantitative adjective: This type of adjective shows a quantity of something. In Kurdish, all quantitative adjectives are compound, and it is made from more than a morpheme (Marf, 2001). There are some affixes that help to made adjective from noun, for example:

- Noun $+\hat{\imath} \quad$ (Kurdîl-Kurdish, Kirmancî-Kurmanj, eşîrî - tribal)

- Noun + în (zîvîn-silverish, zêrîn-golden)

- Noun + ane (jinane - feminine, mêrane - manlike)

- Noun + e (havine - summertime, payze - autumnal).

Also, the types of adjectives that mentioned below can be categorized within quantitative adjective. However, some researchers would claim that they are independent parts of adjective (Yildirim, 2012). We believe that there is quantity on their meaning, so that we categorize them here;

a) Numeric adjective: As a general rule, adjective will follow noun in Kurdish. So, all the numbers that determinate a noun and following it are adjective. For example; pola şeşem - sixth class, navê hewtem - Seventh name.

b) Possessive adjective: In other languages, possessive is a part of adjective as well. Kurdish possessive adjective is following noun. For example; mala min - my house, mala to - your house, tiştên min - things of mine.

c) Interrogative adjective: It asks about the quantity of something, for example; chiqas nan lazim e? How much bread do you need?

d) Demonstrative adjective: For example; mînak - like that, wisa - like this. 
3. Adjectives for absence: This kind of adjective is generally dependant, and its meaning linked with context (Wehbi, 1929, pp. 78 -80). For example:

- tir, din, dike - other

- hinek-some

- hiç - none.

\section{Types of adjective in terms of structure}

Adjective might be categorized in terms of its structure. Is it simple? or is it compound? Which depends on that the adjective consists of one morpheme or more. The compound adjective also has two types, the first one is consists of one dependent morpheme and one an independent morpheme, while the second one is consists of two independent morphemes or more (Yildirim, 2012) (Marf, 2001).

These are the types of Kurdish adjective in terms of structure:

\section{Simple adjectives:}

All adjectives that consist of only one independent morpheme are categorized here, and it is some Kurdish examples of this type (Table 2):

Table 1: Some adjectives that consist of only one independent morpheme

\begin{tabular}{llll}
\hline $\begin{array}{l}\text { Kurdish - Northern } \\
\text { Kurmanji }\end{array}$ & $\begin{array}{l}\text { Kurdish - Central } \\
\text { Kurmanji }\end{array}$ & Kurdish - Zazaki & English \\
\hline Bed - xirab & Bed-xirap & xirab & nasty \\
roşin & roşin & roşn & vivid \\
ejêb & Seyr - ejêb & ejêb & weird \\
ciwan, xweşik & ciwan & Ciwan - weş & nice \\
giring & giring & giran & important \\
dîn & şet & xint & mad \\
$n \hat{u}$ & $n w \hat{e}$ & newe & new \\
\hline
\end{tabular}

\section{Compound adjectives:}

Adjectives may be compound. It basically means that the adjective consists of more than one morpheme. It would be added a dependent morpheme that does not have meaning independently, or independent morpheme that has its own special meaning.

A. Compound adjectives that made by an independent morpheme and a prefix or suffix;

- Prefix + an independent morpheme, for example:

Table 2: Compound adjectives that made by an independent morpheme and a prefix

\begin{tabular}{llll}
\hline $\begin{array}{l}\text { Kurdish - Northern } \\
\text { Kurmanji }\end{array}$ & $\begin{array}{l}\text { Kurdish - Central } \\
\text { Kurmanji }\end{array}$ & Kurdish - Zazaki & English \\
\hline$\underline{\text { bihêz }}$ & $\underline{\text { Behêz - beqiwet }}$ & $\underline{\text { bêqewet }}$ & Strong \\
$\underline{\text { namerd }}$ & $\underline{\text { namerd }}$ & $\underline{\text { namerd }}$ & Coward \\
jêhatî & $\underline{\text { lêhat }}$ & jîhatî & Skilful
\end{tabular}




nexweş nexoş nệweş Unhealthy

- An independent morpheme + suffix

Table 3: Compound adjectives that made by an independent morpheme and a suffix

\begin{tabular}{|c|c|c|c|}
\hline $\begin{array}{l}\text { Kurdish - Northern } \\
\text { Kurmanji }\end{array}$ & $\begin{array}{l}\text { Kurdish - Central } \\
\text { Kurmanji }\end{array}$ & Kurdish - Zazaki & English \\
\hline Zana & Zana & Zana & Astute \\
\hline Runak & Runak - Roşin & $\operatorname{Roșn}$ & Light \\
\hline Dewlemend & Dewlemend & Dewlemend & Rich \\
\hline Rojane & Rojane & Rojane - rojkik & Daily \\
\hline
\end{tabular}

B. Compound adjectives that made by two independent morphemes or more, for example (Marf, 2001) (Yildirim, 2012):

- $\quad$ Noun + Noun

- Noun + Adjective

- Noun + participle

- $\quad$ Adjective + noun

- $\quad$ Adjective $+\mathrm{e}+$ noun

- Noun + base form

- Adjective + verb base insight

- Number + noun

- Adverb + noun

- Adverb + verb base

- Noun Reputation

- Adjective Reputation

- Adjective $+\hat{u}+$ Adjective

- $\quad$ Adjective $+\hat{u}+$ a word that does not have meaning
Bejinziraf - tall, çavxezal - eyes like doe

Çavreş - black eye, bextreş - unlucky

dilşikestî-aggrieved

kêmaqil - foolish

kalemêr - old man, pîrejin - old woman

Serbest - free, mêrkuj - murder

Rastbêj - honest, dûrbîn - someone who have great

Dûdil - hesitant, dûru - deceitful

Jêrdest - a person or persons who are not free

pirbêj- talkative

Kunkun - something with lots of orifices.

Gulgulî - flowery

ciwan ciwan - nice, hur hur - accurate

Sorûspî - A person whose skin is like European

people, kerûlal - deaf and dumb

lezûbez

\section{Adjective forms of comparative degree}

Obviously, each type of word has its specification, for example verbs might be past, present, or future. Nouns would be definite or indefinite. Adjectives has also their specifications, and the main specifications of adjectives is comparison. These articles, which are used to make an adjective comparative and superlative, are taking grammatical role not a semantic role. Kurdish, like other languages has its way to make a comparison, which is shown below: 


\section{Positive 'base' form:}

These are the simple adjectives that simply describe the noun without comparing it to another. For example;

Ew kurêkî bașe. He is a good boy.

Iro heva xwesse. Today is a nice day.

\section{Comparative form:}

This form is used when we are comparing two nouns, and need to show which noun possesses the adjective or character in a greater or lesser amount, when compared with the other. In Kurdish, generally comparison is made by adding 'tir' as a suffix for the positive adjective, for instance;

Table 4: Comparative form that are made by a suffix

\begin{tabular}{lll}
\hline Positive form & Comparative form & Meaning in English \\
\hline bilezzet & bilezzettir & Dainty - daintier \\
kêmaqil & kêmaqiltir & dumb-dumber \\
çeleng & çeleng tir & gracious - more gracious \\
\hline
\end{tabular}

Also, in syntax there are other ways to build it, some independent words might come before the positive form and the complete meaning become comparison, for example;

Table 5: Comparative form that are made by another independent morpheme

\begin{tabular}{|c|c|c|}
\hline $\begin{array}{l}\text { Word making } \\
\text { comparison form }\end{array}$ & Comparative form & Meaning in English \\
\hline zêdetir & Ev enare & $\begin{array}{l}\text { More - This pomegranate is sourer than } \\
\text { the other one. }\end{array}$ \\
\hline kêmtir & Ev enare kêmtir tirș $e$. & $\begin{array}{l}\text { Less - This pomegranate is less sour than } \\
\text { the other one. }\end{array}$ \\
\hline
\end{tabular}

\section{Superlative form}

This form is used when three or more nouns are being compared and we need to show that one or more of the nouns possess the adjective or characteristic to the highest amount possible. In Kurdish, superlative is made by adding ' tirîn' for the positive form. For example;

Table 6: Superlative form that is made by a suffix

\begin{tabular}{llll}
\hline Positive form & Comparative form & Superlative form & $\begin{array}{l}\text { Meaning in } \\
\text { English }\end{array}$ \\
\hline bextreş & Bextreştir & bextreştirîn & Unlucky \\
tarî & Tarîtir & tarîtirîn & Dark \\
Serbest & Serbesttir & Serbesttirîn & Free \\
\hline
\end{tabular}


Also, in syntax there are other ways to build superlative form, some independent words might come before the positive form and the complete meaning become superlative, for example;

Table 7: Superlative form that is made by another independent morpheme

\begin{tabular}{lll}
\hline Word making superlative form & Superlative form & Meaning in English \\
\hline Herî + base form & Herî baş & The most \\
Le hemî tişit + comparative form & Le hemî tişit baştir & The most \\
\hline
\end{tabular}

\section{Some differences between Kurdish adjective and adjective in Persian}

Kurdish and Persian are both Iranian languages, and they have many similarities. Regarding adjectives, this type of word is very similar with Kurdish. There are some adjectives are totally same. Also, comparative and superlative forms of adjective are made in the same way, and the suffixes are very similar, however there are small differences between phonology of the suffixes. As been discussed, Kurdish positive adjective become comparative by 'tir' and superlative by 'tirîn'. Also, Persian language uses 'ter, terîn' for comparative and superlative forms (Enwari, 1390, p. 54). For example;

Table 8: comparing Kurdish and Persian adjectives.

\begin{tabular}{llll}
\hline Positive form & $\begin{array}{l}\text { Comparative } \\
\text { form }\end{array}$ & Superlative form & Positive form meaning \\
\hline Biçuk (Kurdish) & Biçuktir & Biçuktirîn & Small \\
Kuçik(Persian) & Kuçikter & Kuçikterîn & \\
\hline Mezin (Kurdish & Mezintir & Mezintirîn & Big \\
Bozorg (Persian) & bozorgter & bozorgterîn & \\
\hline baş (Kurdish) & Baştir & Baştirîn & Good \\
xub (Persian) & xubter & xubterîn & \\
\hline
\end{tabular}

Regarding English, In some types of adjective 'er, est' is added as suffixes to make comparative and superlative forms of adjective, while long adjectives need independent morphemes 'more, most' in front of them to become comparative and superlative. Also there are certain order in English when more than an adjective is used (Amer, 2013), while there are not such rules in Kurdish. This means that there are more differences than similarities between English and Kurdish adjectives.

\section{CONCLUSION}

Adjective in Kurdish can be defined in terms of meaning and structure. Most adjectives are similar between Kurdish dialects, however, there are some different adjectives that have same meaning but they are different in terms of structure and phonologically. The examples prove this view and confirm that the mentioned dialects of Kurdish 'Northern Kurmanji, Central Kurmanji, and Zazaki' are very similar in terms of morphology, and there are some phonetic changes in specific situations. 
There are many compound adjectives in Kurdish, different ways are used to make them. Compound adjective would be made by suffixes or prefixes with an independent morpheme, or two independent morphemes would make a new compound adjective.

Due to language contact, some words come into Kurdish language from other languages like Arabic, but they pretend as Kurdish word, and they are used under Kurdish grammar rules. The comparison is made by 'tir' for comparative form 'tirin' for superlative form, which is very similar with making comparison in Persian. In contrast of English language, in Kurdish, there are not certain order when more than one adjective is used for describe a noun.

\section{REFERENCES}

Amer, W. M. (2013). An investigation into the differences between English and Arabic position and order of adjectives: A contrastive study with pedagogical implications. Red Sea University Journal, 21-48.

Baker, M. C. (2003). Lexical categories; Verbs, Nouns, and Adjectives. Cambridge: Cambridge University Press.

Oxford's Dictionary. (2016). Oxford dictionaries, language matters . Retrieved from http://www.oxforddictionaries.com/words/adjectives

Enwari, H. (1390). The rules of Persian language (In Persian). Esfehan: Online. Retrieved from http://www.8pic.ir/images/dtbo11n2um54fg4tdzj.pdf

Marf, A. H. (2001). Rezmani Kurdi (1). Sulaimanya: Tishk Publication.

Wehbi, T. (1929). desturi zmani Kurdi. Baghdad.

Yildirim, K. (2012). Temel Alistirma ve Metinlerle Kurtce Dilbilgisi (Kurmanji Lehcesi). Mardin: Mardin Artuklu Universitesi. 